\title{
Exergoeconomic Analysis of Plum Drying in a Heat Pump Conveyor Dryer
}

\author{
Arif Hepbasli , Neslihan Colak , Ebru Hancioglu , Filiz Icier \& Zafer Erbay
}

To cite this article: Arif Hepbasli , Neslihan Colak , Ebru Hancioglu , Filiz Icier \& Zafer Erbay (2010) Exergoeconomic Analysis of Plum Drying in a Heat Pump Conveyor Dryer, Drying Technology, 28:12, 1385-1395, DOI: 10.1080/07373937.2010.482843

To link to this article: http://dx.doi.org/10.1080/07373937.2010.482843

\section{Published online: 24 Nov 2010.}

Submit your article to this journal $\lceil\pi$

Џ Article views: 302

Q View related articles $₫$

4 Citing articles: 15 View citing articles $\asymp$ 


\title{
Exergoeconomic Analysis of Plum Drying in a Heat Pump Conveyor Dryer
}

\author{
Arif Hepbasli, ${ }^{1}$ Neslihan Colak, ${ }^{2}$ Ebru Hancioglu, ${ }^{3}$ Filiz Icier, ${ }^{4}$ and Zafer Erbay ${ }^{4}$ \\ ${ }^{1}$ Department of Mechanical Engineering, College of Engineering, King Saud University, Riyadh, \\ Kingdom of Saudi Arabia \\ ${ }^{2}$ Department of Food Engineering, Faculty of Engineering, Pamukkale University, Denizli, Turkey \\ ${ }^{3}$ Geothermal Energy Research and Application Center, Izmir Institute of Technology, Izmir, Turkey \\ ${ }^{4}$ Department of Food Engineering, Faculty of Engineering, Ege University, Izmir, Turkey
}

\begin{abstract}
In this study, plum slices were dried in a heat pump dryer designed and constructed in Ege University, Izmir, Turkey. Drying experiments were carried out at an air temperature range of $45-55^{\circ} \mathrm{C}$. The performance of the dryer along with its main components were evaluated using an exergy analysis method. Exergy destruction and capital cost rates were used for the exergoeconomic analysis, which is based on the quantities exergy, cost, energy, and mass (EXCEM) method. Exergy destruction rates to capital cost values $R_{e x}$ were obtained to vary between 1.668 and $2.063 \mathrm{~W} /$ USD at different drying air temperatures. $R_{e n}$ values were observed to range from 6.258 to $5.749 \mathrm{~W} / \mathrm{USD}$. $R_{e n}$ values decreased as the drying air temperature increased, contrary to $R_{e x}$ values. $\dot{R}_{e x}$ and $\dot{\boldsymbol{R}}_{e n}$ values increased linearly with increasing temperature due to the loss, whereas $\dot{\boldsymbol{R}}_{e n}$ decreased due to the relatively higher energy utilization efficiency of the heat pump. In the compressor, $\dot{R}_{e n}$ and $\boldsymbol{R}_{e x}$ values decreased with the increase in the temperature contrary to the other components. $\dot{\boldsymbol{R}}_{e x}$ had the lowest value in the drying duct. However, in the compressor, expansion valve, and heat recovery, $\dot{\boldsymbol{R}}_{e x}$ values were found to be higher and should be improved in these units.
\end{abstract}

Keywords Exergoeconomic analysis; Food drying; Heat pump dryer

\section{INTRODUCTION}

Drying is one of the oldest unit operations and has been widely used in various industries in recent years. In the food industry, foods are dried starting from their natural form (vegetables, fruits, grains, spices, milk) or after handling (e.g., instant coffee, soup mixes, whey). The production of a processed food may involve more than one drying process at different stages, and in some cases pretreatment of food is necessary before drying. The main purpose of food drying is to preserve and extend the shelf life of the product. In addition, drying in the food industry is used to (1) obtain the desired physical form (e.g., powder,

Correspondence: Arif Hepbasli, Department of Mechanical Engineering, College of Engineering, King Saud University, P.O. Box 800, Riyadh 11421, Kingdom of Saudi Arabia; E-mail: ahepbasli.c@ksu.edu.sa or arifhepbasli@gmail.com flakes, granules); (2) obtain the desired color, flavor, or texture; (3) reduce volume or weight for transportation; (4) and produce new products that would not otherwise be feasible. ${ }^{[1,2]}$ The methods of drying are diversified with the purpose of the process. There are more than 200 types of dryers. ${ }^{[1]}$ For every dryer, the process conditions, such as drying chamber temperature, pressure, air velocity (if the carrier gas is air), relative humidity, and product retention time, have to be determined according to feed, product, purpose, and method. Drying is an energy-intensive process, and its energy consumption value is $10-15 \%$ of the total energy consumption in all industries in developed countries. ${ }^{[1,3]}$ So optimization of drying processes and systems is important in terms of their energetic efficiencies.

During the past few decades, thermodynamic analyses, particularly exergy analyses, have appeared to be an essential tool for the system design, analysis, and optimization of thermal systems. From a thermodynamic point of view, exergy is defined as the maximum amount of work that can be produced by a stream of matter, heat, or work as it comes to equilibrium with a reference environment. Exergy is not subject to a conservation law; rather exergy is consumed or destroyed, due to irreversibilities in any process. It is a measure of the potential of a stream to cause change, as a consequence of not being completely stable relative to the reference environment. For this reason, the state of the reference environment, or the reference state, must be specified completely. This is commonly done by specifying the temperature, pressure, and chemical composition of the reference environment. ${ }^{[4]}$ By using an exergy analysis method, magnitudes and locations of exergy destructions (irreversibilities) in the whole system can be identified, and potential for energy efficiency improvements can be introduced. ${ }^{[5]}$ Mathematical models for exergy analysis of drying of biological products have been developed by some investigators. $^{[4,6-9]}$ The energy analysis method has been widely used for evaluating the performance of food systems 
(especially food dryers), though studies on exergy analysis are relatively few in numbers. ${ }^{[10-15]}$

Exergoeconomic analysis helps designers to find ways to improve the performance of a system in a cost-effective way. ${ }^{[16]}$ Many researchers have developed methods of performing economic analyses based on exergy, which are referred to by a variety of names (e.g., thermoeconomics, second law costing, cost accounting, and exergoeconomics $).{ }^{[17-20]}$

Exergoeconomic analysis has been applied to various energy-related systems, such as the residential commercial sector, ${ }^{[21]}$ thermal systems, ${ }^{[22]}$ power plants, ${ }^{[17]}$ combined cycle cogeneration plants, ${ }^{[23]}$ and diesel engine-powered cogeneration. ${ }^{[2]}$ Based on a literature survey, no studies have appeared on the exergoeconomic analysis of heat pump drying systems to the best of the authors' knowledge. This was the prime motivation in doing the present study, which applied the exergy, cost, energy, and mass (EXCEM) method to a heat pump system for drying of plums slices, and the performance assessment for each component of this system and the whole system was done using the exergy analysis method. The effect of drying temperature on the efficiencies of the systems was also evaluated in terms of exergetic efficiency, improvement potential rate, and exergoeconomic analysis. In this regard, the authors investigate the relations between thermodynamic losses and capital costs for devices in the heat pump drying system based on the experimental data and actual cost and suggest possible generalizations in the relation between thermodynamic losses and capital costs. Suggestions for improving the efficiencies of the drying systems are also made. This work also provides insight that will aid investigators, designers, and operators of such systems.

\section{MATERIALS AND METHODS \\ Material}

Freshly harvested plums (Prunus domestica Insititia) were purchased from a local market in Izmir, Turkey. The purchased plums were cleaned and dipped into $1 \% \mathrm{NaOH}$ solution for $15 \mathrm{~s} .{ }^{[25,26]}$ Plums were then washed with water and, after removing the excess water on the surface of plums with a filter paper, sliced uniformly (average thickness: $4.0 \pm$ $0.5 \mathrm{~mm}$ ). The purchased plums were processed within $24 \mathrm{~h}$.

The moisture content of the plums was determined using a vacuum oven method. ${ }^{[27]}$ The moisture content of the fresh and dried plums was determined to be $84.49 \% \pm$ 1.10 and $15.70 \% \pm 2.56$, respectively.

\section{Experimental Setup}

Plums were dried in the heat pump dryer. A pilot-scale heat pump conveyor dryer, which was designed and constructed in the Department of Mechanical Engineering, Faculty of Engineering, Ege University (Izmir,

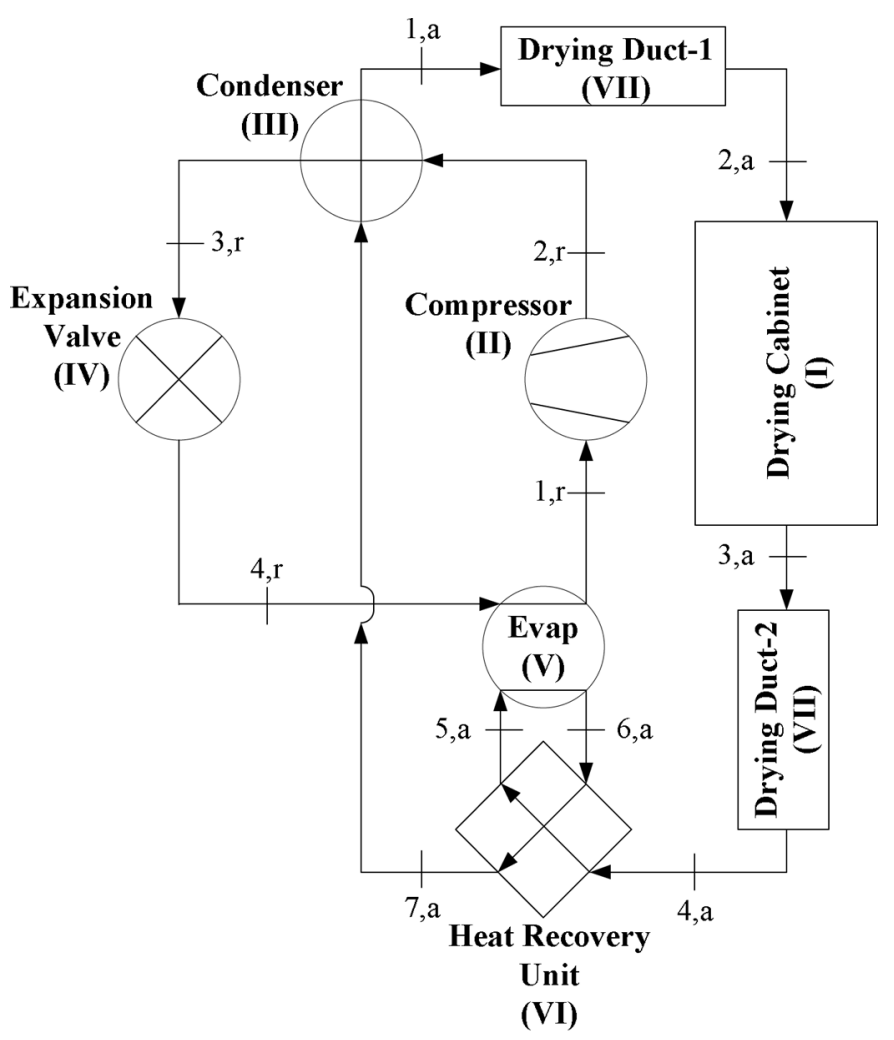

(a)

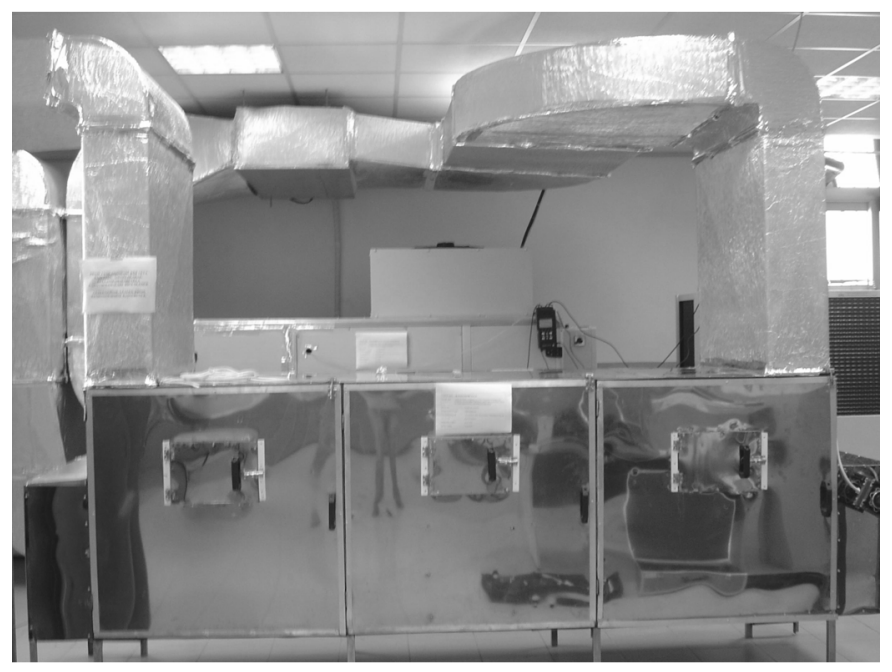

(b)

FIG. 1. (a) Schematic of the heat pump dryer with coded points used in equations; (b) Picture of the heat pump dryer.

Turkey), was used in this study. ${ }^{[14]}$ Figure 1a shows a schematic diagram of the heat pump dryer, and a picture is shown in Fig. 1b. The drying system consisted of two main parts, namely, (1) the heat pump and (2) the drying chamber. The air was heated by the heat pump system, which included a scroll compressor, two condensers (internal and external ones), the expansion valve, the evaporator, 
and a heat recovery unit. R407C was used as refrigerant in the heat pump system. The $\mathrm{R} 407 \mathrm{C}$ at a low pressure is vaporized in the evaporator by extracting heat from the air. The compressor raises the enthalpy of the R407C of the heat pump and discharges it as superheated vapor at a high pressure. Heat is removed from the $\mathrm{R} 407 \mathrm{C}$ and returned to the process air at the condenser. The $\mathrm{R} 407 \mathrm{C}$ is then throttled to a low-pressure line (using an expansion valve) and enters the evaporator to complete the cycle. In the cabinet drying system, the hot air at the exit of the condenser is allowed to pass through the drying chamber where it gains heat from the product to be dried. Some of the fresh air from the ambient air is mixed with the moist air expelled from the drying chamber before entering to the condenser. The air temperature is controlled by a control unit. The drying air velocity is regulated by a fan and its speed control unit, and the drying air is recycled. Drying compartment dimensions are $3.0 \times 1.0 \times 1.0 \mathrm{~m}$. Plums are moved by a conveyor band system driven by an electric motor.

\section{Drying Procedure and Measurements}

Plum slices were spread onto trays as a thin layer. Drying experiments were carried out at drying air temperatures of 45 , 50 , and $55^{\circ} \mathrm{C}$ with a drying air velocity of $1.5 \mathrm{~m} / \mathrm{s}$. Humidities, temperatures, and velocities were measured in the drying chamber with robust humidity probes (0636.2140, Testo, Freiburg, Germany), vane/temperature probes (0635.9540, Testo), and professional telescopic handle for plug-in vane probes (0430.0941, Testo), respectively. Measurements of drying air temperature, velocity, and relative humidity were recorded every $5 \mathrm{~min}$. An infrared thermometer (552-T2, Testo) and a surface thermometer (ME-32, Metex, Seoul, South Korea) were used to measure the surface temperatures of product and drying chamber walls, respectively. A digital balance (SBA 61, Scaltec, Göttingen, Germany) was used to measure the weight loss of the sample during drying experiments. The ambient temperature and relative humidity were also measured and recorded. Pressures and temperatures of the refrigerant were measured using pressure probes (low/high pressure probes, 0638.01941, Testo) and surface temperature probes (temperature probes, 0628.0019, Testo), respectively. All measured values were observed and recorded with a multifunction instrument (control unit 350-XL/454, Testo) and loggers.

\section{ANALYSIS \\ Assumptions Made}

The following assumptions were used during the analyses:

1. All processes were steady state and steady flow with negligible potential and kinetic energy effects and no chemical or nuclear reactions.
2. The heat transfer to the system and the work transfer from the system were positive.

3. The heat transfer and refrigerant pressure drops in the tubing connecting the components were neglected because their lengths are short.

4. The compressor mechanical $\eta_{\text {comp,mech }}$ and the compressor motor electrical $\eta_{\text {comp,elec }}$ efficiencies were 72 and $75 \%$, respectively. ${ }^{[28]}$

5. Air was an ideal gas with a constant specific heat.

6. The reference (dead) state conditions were determined to be $T_{0}=10^{\circ} \mathrm{C}, P_{0}=101.325 \mathrm{kPa}$, and $\sigma_{0}=60 \%$ for the air and $T_{0}=10^{\circ} \mathrm{C}$ and $P_{0}=101.325 \mathrm{kPa}$ for the refrigerant.

7. $C p_{a}=1.005 \mathrm{~kJ} / \mathrm{kg} .{ }^{\circ} \mathrm{C}, \quad C p_{v}=1.872 \mathrm{~kJ} / \mathrm{kg} .{ }^{\circ} \mathrm{C}, \quad R_{a}=$ $0.287 \mathrm{~kJ} / \mathrm{kg} . \mathrm{K}$, and $R_{v}=0.4615 \mathrm{~kJ} / \mathrm{kg} . \mathrm{K}$ were assumed as constant in all calculations. ${ }^{[29]}$ The thermodynamic properties of air and $\mathrm{R} 407 \mathrm{C}$ were found using the Engineering Equation Solver (EES) software package. ${ }^{[30]}$

\section{Exergetic Analysis Relations}

For a general steady-state, steady-flow process, the three balance equations, namely, mass, energy, and exergy balance equations, were employed to find the heat input, the rate of exergy destruction, and energy and exergy efficiencies. $^{[31]}$

In general, the mass balance equation can be expressed in the rate form as

$$
\sum \dot{m}_{i n}=\sum \dot{m}_{\text {out }}
$$

The general energy balance can be written as the total energy input equal to total energy output

$$
\sum \dot{E}_{\text {in }}=\sum \dot{E}_{\text {out }}
$$

with all energy terms as follows:

$$
\dot{Q}+\sum \dot{m}_{\text {in }} h_{\text {in }}=\dot{W}+\sum \dot{m}_{\text {out }} h_{\text {out }}+Q_{\text {loss }}
$$

For the drying processes, the energy balance can be written by applying the first law of thermodynamics or the law of conservation of energy for the control volume. The significant heat transfer is due to the heat of evaporation between the solid and the drying air, and there is also heat transfer with the surroundings. Here, $\dot{Q}_{\text {loss }}$ is the energy loss or waste energy output and is to be heat transfer with the surroundings. It is also assumed that all kinetic and potential energy effects are ignored. 
The general exergy balance is expressed in the rate form as

$$
\sum \dot{E} x_{i n}=\sum \dot{E} x_{o u t}+\sum \dot{E} x_{d}
$$

Exergy destruction associated with the irreversibilities (entropy generation) within the system boundaries and exergy losses associated with the transfer of the exergy (through material and energy streams) to the surroundings $\operatorname{are}^{[31]}$

$$
\begin{gathered}
\dot{E} x_{\text {heat }}-\dot{E} x_{\text {work }}+\dot{E} x_{\text {mass }, \text { in }}-\dot{E} x_{\text {mass }, \text { out }}=\dot{E} x_{d} \\
\sum\left(1-\frac{T_{0}}{T_{b}}\right) \dot{Q}_{b}-\dot{W}+\sum \dot{m}_{\text {in }} \text { ex } x_{\text {in }} \\
-\sum \dot{m}_{\text {out }} \text { ex } x_{\text {out }}=\dot{E} x_{d}
\end{gathered}
$$

with

$$
\dot{E} x=\dot{m} . e x
$$

The specific exergy (e.g., flow exergy) of the components such as the refrigerant, water, and air is calculated by ${ }^{[4]}$

$$
\begin{gathered}
e x_{r, w}=\left(h-h_{0}\right)-T_{0}\left(s-s_{0}\right) \\
e x_{a}=\left(C p_{a}+\omega_{a} C p_{v}\right)\left(T_{a}-T_{0}\right)-T_{0}\left[\left(C p_{a}+\omega_{a} C p_{v}\right)\right. \\
\left.\ln \left(\frac{T_{a}}{T_{0}}\right)-\left(R_{a}+\omega_{a} R_{v}\right) \ln \left(\frac{P_{a}}{P_{0}}\right)\right] \\
+T_{0}\left[\left(R_{a}+\omega_{a} R_{v}\right) \ln \left(\frac{1+1,6078 \omega_{0}}{1+1,6078 \omega_{a}}\right)\right. \\
\left.+1,6078 \omega_{a} R_{a} \ln \left(\frac{\omega_{a}}{\omega_{0}}\right)\right]
\end{gathered}
$$

The energy-based performance (or the coefficient of performance, $C O P$ ) of the heat pump (HP) unit and the whole HP dryer system is calculated as follows, respectively:

$$
\begin{aligned}
C O P_{H P, \text { theoretical }} & =\frac{\left(h_{2, r s}-h_{3, r}\right)}{\left(h_{2, r s}-h_{1, r}\right)} \\
C O P_{H P, a c t} & =\frac{\dot{Q}_{\text {cond }}}{\dot{W}_{\text {comp }}}
\end{aligned}
$$

Exergy efficiency is defined as the ratio of total exergy out to total exergy in where out refers to net output, product, or desired value, and in refers to given, used, or fuel.

$$
\eta=\frac{\dot{E} x_{\text {out }}}{\dot{E} x_{\text {in }}} \times 100
$$

Van Gool ${ }^{[32]}$ has proposed that maximum improvement in the exergy efficiency for a process or system was obviously achieved when the difference between total exergy output and total exergy input was minimized. Consequently, he suggested that it was useful to employ the concept of an exergetic improvement potential in the rate form when analyzing different processes or sectors of the economy and this improvement potential in the rate form is given by the relation ${ }^{[33]}$

$$
I \dot{P}=(1-\eta)\left(\dot{E} x_{\text {in }}-\dot{E} x_{\text {out }}\right)
$$

Mass and energy balances as well as exergy destructions and exergetic efficiencies obtained from exergy balances for each of the drying system components are given in the Appendix.

\section{Exergoeconomic Analysis Relations}

Thermodynamic losses are considered two types. These are described in Eqs. (2a) and (3) as differential forms of the thermodynamic balances.

Energy losses can be identified directly from the energy balances in Eqs. (2a) and (2b). For convenience, the energy loss rate for a system is denoted in the present analysis as $\dot{L}_{e n}$ (loss rate based on energy). Because there is only one loss term, the waste energy output in Eq. $(2 b)^{[17]}$ is given by

$$
\dot{L}_{e n}=\text { Waste energy output rate }
$$

Exergy losses can be identified from the exergy balance in Eq. (3). There are two types of exergy losses, namely, the waste exergy output, which represents the loss associated with exergy that is emitted from the system, and the exergy consumption, which represents the internal exergy loss due to process irreversibilities. These two exergy losses sum to the total exergy loss. Hence, the loss rate based on exergy, $\dot{L}_{e x}$, is defined as ${ }^{[17]}$

$\dot{L}_{e x}=$ Exergy consumption rate + Waste exergy output rate

The capital cost is defined here using the cost balances in Eq. (12) is denoted by $K$. Capital cost is simply that part of the cost generation attributable to the cost of equipment:

$$
K=\text { Capital cost of equipment }
$$

For a thermal system operating normally in a continuous steady-state, steady-flow process mode, the accumulation terms in Eqs. (1)-(3) are zero. Hence all losses are associated with the already discussed terms $\dot{L}_{e n}$ and $\dot{L}_{e x}$. The energy and exergy loss rates can be obtained through 
the following equations ${ }^{[17]}$ :

$$
\dot{L}_{\text {en }}=\sum_{\text {inputs }} \dot{E}-\sum_{\text {products }} \dot{E}
$$

and

$$
\dot{L}_{e x}=\sum_{\text {inputs }} \dot{E} x-\sum_{\text {products }} \dot{E} x
$$

where the summations are over all input streams and all product output streams.

Another parameter, $R$, is used as the ratio of thermodynamic loss rate $\dot{L}$ to capital cost $K$ as follows ${ }^{[17]}$ :

$$
R=\frac{\dot{L}}{K}
$$

The value of $R$ generally depends on whether it is based on energy loss rate, in which case it is denoted $\left(R_{e n}\right)$, or exergy loss rate $\left(R_{e x}\right)$, as follows:

$$
R_{e n}=\frac{\dot{L}_{e n}}{K}
$$

and

$$
R_{e x}=\frac{\dot{L}_{e x}}{K}
$$

Values of the parameter $R$ based on energy loss rate and on total, internal, and external exergy loss rates are considered.

\section{RESULTS AND DISCUSSION}

The energy-based (or first law) performance measure of the HP unit was calculated. Theoretical $C O P$ values of the HP unit were found to be in the range of 3.92-4.35 and they decreased with the increase in the drying temperature. The actual $C O P$ values were obtained to vary between 2.56 and 2.81 for the HP unit.

Table 1 illustrates exergetic analysis data provided for the HP dryer. The highest improvement potential (IP) rate values occurred in the motor-compressor assembly. The other important system components were the heat recovery unit (HRU), expansion valve, and evaporator according to the $I P$ rate values.

Whereas $\eta$ and $I P$ rate values of the compressor were obtained to vary between 52.38 and $64.20 \%$ and 0.99 and $1.48 \mathrm{~kW}$, respectively, $\eta$ values increased as the drying temperature increased contrary t $I P$ rate and $f$ values. The total magnitude of the losses was over $54 \%$ of the actual power input, and mechanical-electrical losses accounted for $46 \%$ of that. Mechanical-electrical losses are due to imperfect electrical, mechanical, and isentropic efficiencies and emphasize the need to pay close attention to the selection of this equipment, because components of inferior performance can considerably reduce overall system performance. Because compressor power depends strongly on the inlet and outlet pressures, any heat exchanger improvements that reduce the temperature difference will reduce compressor power by bringing the condensing and evaporating temperatures closer together. It is obvious that from a design standpoint, the compressor irreversibility can be reduced independently. Recently, scroll-type compressors, which were used in this study, have been recommended due to their high efficiency values. ${ }^{[24,26]}$ An alternative approach to this problem is using primary energy sources instead of electricity. Then the losses arising from energy conversion processes of electricity production can be recovered, and gas engine-driven heat pump systems have this advantage. ${ }^{[34-36]}$

Other important components of the system are heat exchangers (condenser, evaporator, and HRU). It is important to reduce irreversibilities in the evaporator and HRU to improve the system performance. On the other hand, the condenser was separated from other heat exchangers in the system. The highest $\eta$ values were obtained from the condenser in the HP unit. Based on the results of the exergy analysis of the HP dryer, the rise in the drying temperature caused a great decrease in the efficiency of the evaporator. This could be due to increasing the irreversibility as the temperature difference increased. Irreversibilities in the heat exchangers could occur due to the temperature differences between the two heat exchanger fluids, pressure losses, flow imbalances, and heat transfer with the environment.

The expansion valve had the highest $\eta$ values after the condenser in the HP unit. The irreversibility was in the capillary tube due to the pressure drop of the refrigerant passing through it. The only way to eliminate throttling loss would be to replace the capillary tube (the expansion device) with an isentropic turbine (an isentropic expander) and to recover some shaft work from the pressure drop. ${ }^{[24]}$

HP systems are heat-generating devices that transfer heat from a low-temperature medium to a hightemperature one and are used in either hot water or space heating applications. HPs have been used mainly for space heating and water heating/cooling purposes, but many studies have progressed in its industrial applications, especially in dehumidification and in drying agricultural products, which are energy-intensive processes. ${ }^{[37-39]}$ The results of the present study show a good agreement with the literature $\mathrm{e}^{[40,42]}$ and highlight that HP systems are energy efficient and can be integrated to energy-intensive processes.

Figure 2 illustrates the Grassmann (or exergy loss and flow) diagram for the HP dryer. This diagram gives the quantitative information related to the share of exergy 


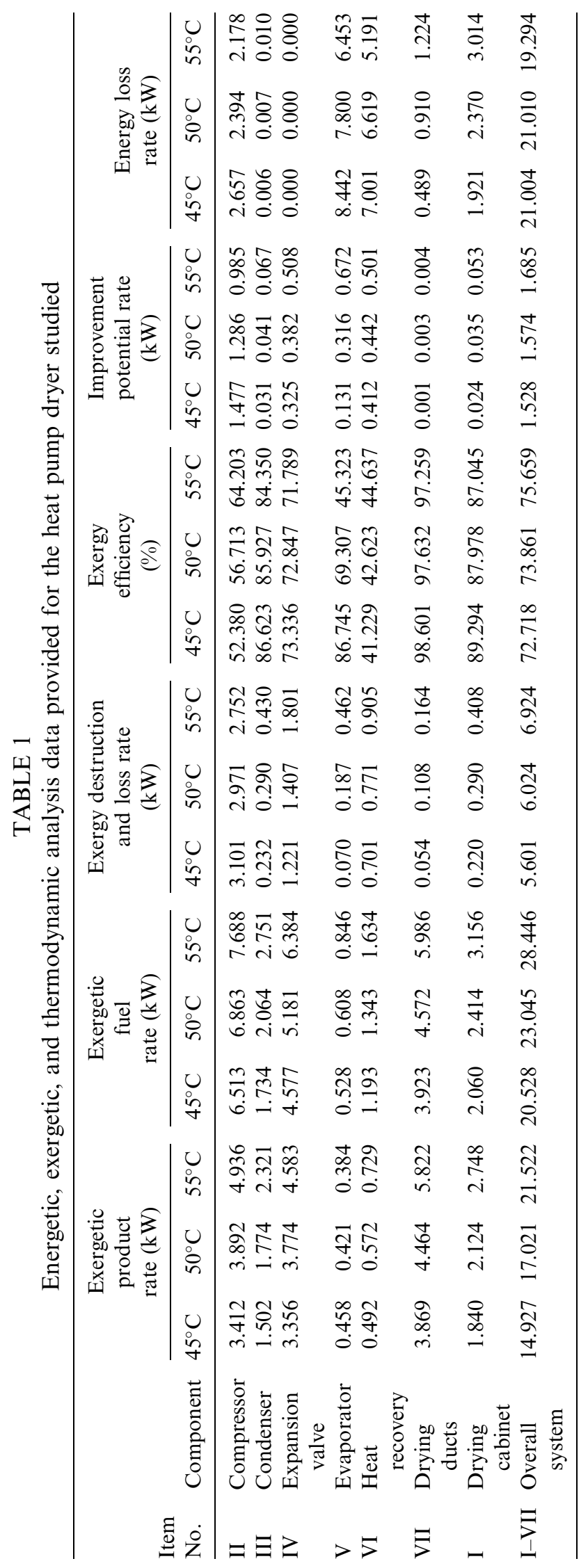




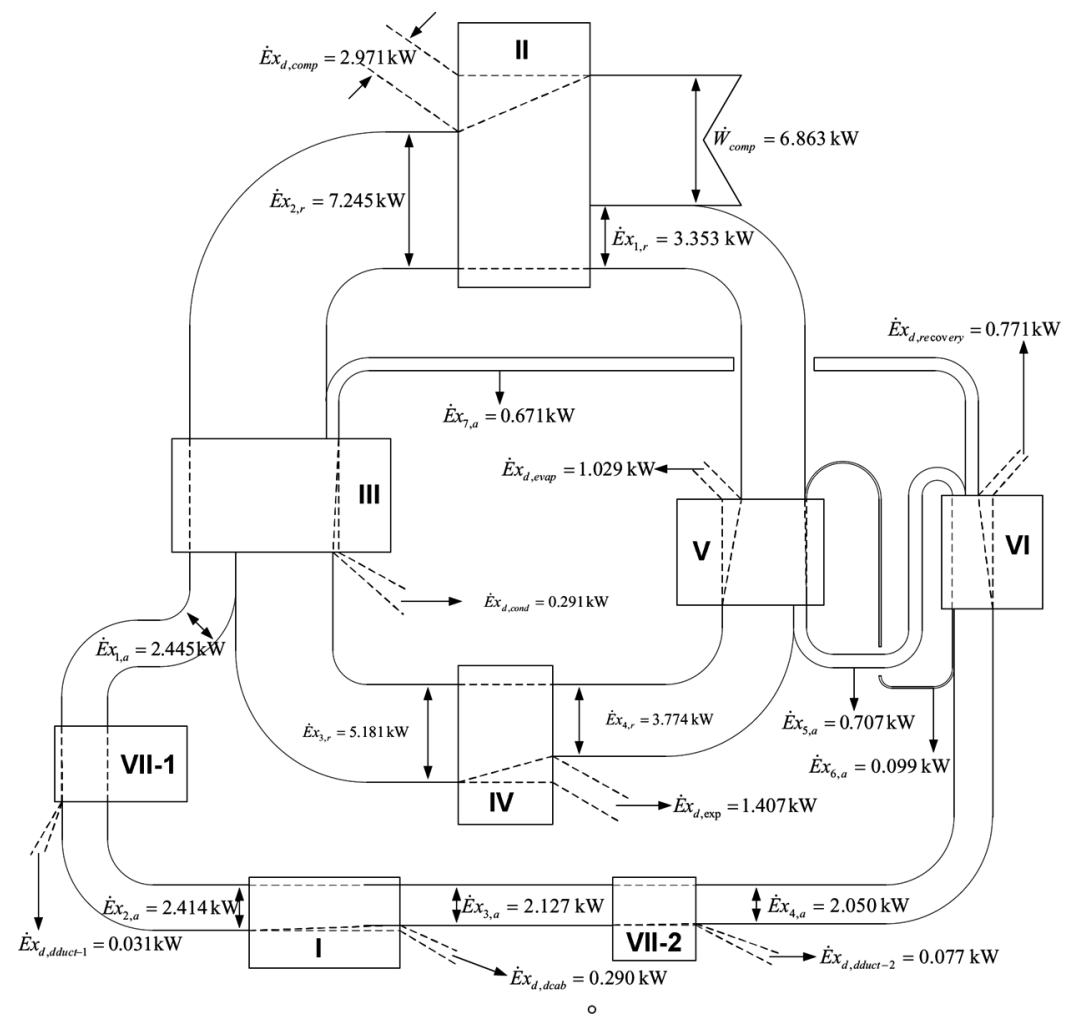

FIG. 2. Exergy loss and flow diagram (Grassmann diagram) for the heat pump dryer at $50^{\circ} \mathrm{C}$.

input to the HP dryer. Though the $\eta$ values were found to vary between 72.72 and $75.66 \%$, the rise in the drying temperature increased the dryer's efficiency.

Table 2 lists the $\dot{L}$ and $\mathrm{R}$ variations for the components of the heat pump system and the whole system. $\dot{R}_{e n}$ values were observed to be between 6.258 and $5.749 \mathrm{~W} / \mathrm{USD}$ for the whole system with the drying air temperatures of 45 , 50 , and $55^{\circ} \mathrm{C}$. Namely, $R_{e x}$ values were found to be in the range of 1.668 and $2.063 \mathrm{~W} / \mathrm{USD}$. $\dot{R}_{e n}$ values decreased as the drying air temperature increased, contrary to $\dot{R}_{e x}$ values. Normally, we expect that $\dot{R}_{e x}$ and $\dot{R}_{e n}$ values increase linearly with increasing the temperature due to the loss, whereas $\dot{R}_{e n}$ decreases because the heat pump is an energy-efficient system. $\dot{R}_{e x}$ increased because of the ambient temperature. Figures 3 and 4 show changing $\dot{R}_{e n}$ and $\dot{R}_{e x}$ values at different drying temperatures, and Figs. 5 and 6 illustrate variations of $\dot{R}_{e n}$ and $\dot{R}_{e x}$ for each component of the system. In the compressor, $\dot{R}_{e n}$ and $\dot{R}_{e x}$ values decreased with the increase in the temperature, contrary to other components. Figure 6 indicates the

TABLE 2

Exergoeconomic parameters of the heat pump dryer system studied

\begin{tabular}{|c|c|c|c|c|c|c|c|c|c|c|c|c|c|}
\hline \multirow[b]{2}{*}{ Item No. } & \multirow[b]{2}{*}{ Component } & \multicolumn{3}{|c|}{$\dot{L}_{e n}(\mathrm{~kW})$} & \multicolumn{3}{|c|}{$\dot{R}_{e n}(\mathrm{~W} / \mathrm{USD})$} & \multicolumn{3}{|c|}{$\dot{L}_{e x}(\mathrm{~kW})$} & \multicolumn{3}{|c|}{$\dot{R}_{e x}(\mathrm{~W} / \mathrm{USD})$} \\
\hline & & $45^{\circ} \mathrm{C}$ & $50^{\circ} \mathrm{C}$ & $55^{\circ} \mathrm{C}$ & $45^{\circ} \mathrm{C}$ & $50^{\circ} \mathrm{C}$ & $55^{\circ} \mathrm{C}$ & $45^{\circ} \mathrm{C}$ & $50^{\circ} \mathrm{C}$ & $55^{\circ} \mathrm{C}$ & $45^{\circ} \mathrm{C}$ & $50^{\circ} \mathrm{C}$ & $55^{\circ} \mathrm{C}$ \\
\hline II & Compressor & 2.657 & 2.394 & 2.178 & 0.792 & 0.713 & 0.649 & 3.101 & 2.971 & 2.752 & 0.923 & 0.885 & 0.819 \\
\hline III & Condenser & 0.006 & 0.007 & 0.010 & 0.002 & 0.002 & 0.003 & 0.232 & 0.290 & 0.430 & 0.069 & 0.086 & 0.128 \\
\hline IV & Expansion valve & 0.000 & 0.000 & 0.000 & 0.000 & 0.000 & 0.000 & 1.221 & 1.407 & 1.801 & 0.363 & 0.419 & 0.536 \\
\hline V & Evaporator & 8.442 & 7.800 & 6.453 & 2.515 & 2.324 & 1.923 & 0.070 & 0.187 & 0.462 & 0.020 & 0.055 & 0.137 \\
\hline VI & Heat recovery & 7.001 & 6.619 & 5.191 & 2.086 & 1.972 & 1.547 & 0.701 & 0.771 & 0.905 & 0.208 & 0.229 & 0.269 \\
\hline VII & Drying ducts & 0.489 & 0.910 & 1.224 & 0.146 & 0.271 & 0.365 & 0.054 & 0.108 & 0.164 & 0.016 & 0.032 & 0.048 \\
\hline I & Drying cabinet & 1.921 & 2.370 & 3.014 & 0.572 & 0.706 & 0.898 & 0.220 & 0.290 & 0.408 & 0.065 & 0.086 & 0.121 \\
\hline I-VII & Overall system & 21.004 & 21.010 & 19.294 & 6.258 & 6.260 & 5.749 & 5.601 & 6.024 & 6.924 & 1.668 & 1.794 & 2.063 \\
\hline
\end{tabular}




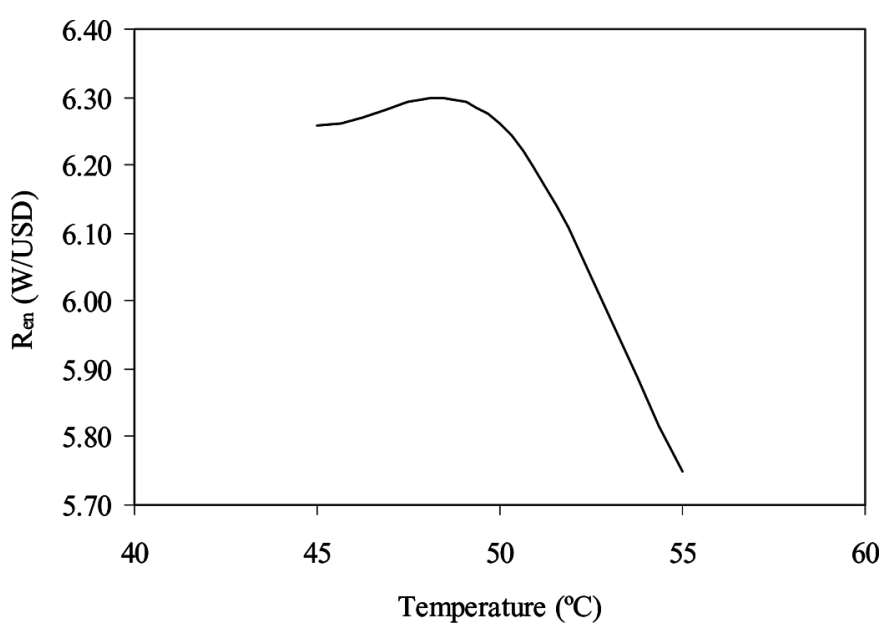

FIG. 3. Variation of $\dot{R}_{e n}$ for the whole system with different drying air temperatures.

lowest value of $\dot{R}_{e x}$ in the drying duct. However, in the compressor, expansion valve, and heat recovery, $\dot{R}_{e x}$ values were high and should be improved in these units. Thus, we can obtain not only energy efficiency but also cost savings.

Capital costs are often the most significant component of the total cost generation. The observation that the mean $R$ value for the devices in a given system is approximately equal to the overall station $R$ value (based on total and internal exergy loss) may indicate that devices in a successful system are arranged to achieve an optimal overall system configuration. However, such an indication is evident from the relations for the devices between capital cost and exergy loss (total and internal) but not between energy loss or external exergy loss and capital cost. In other words,

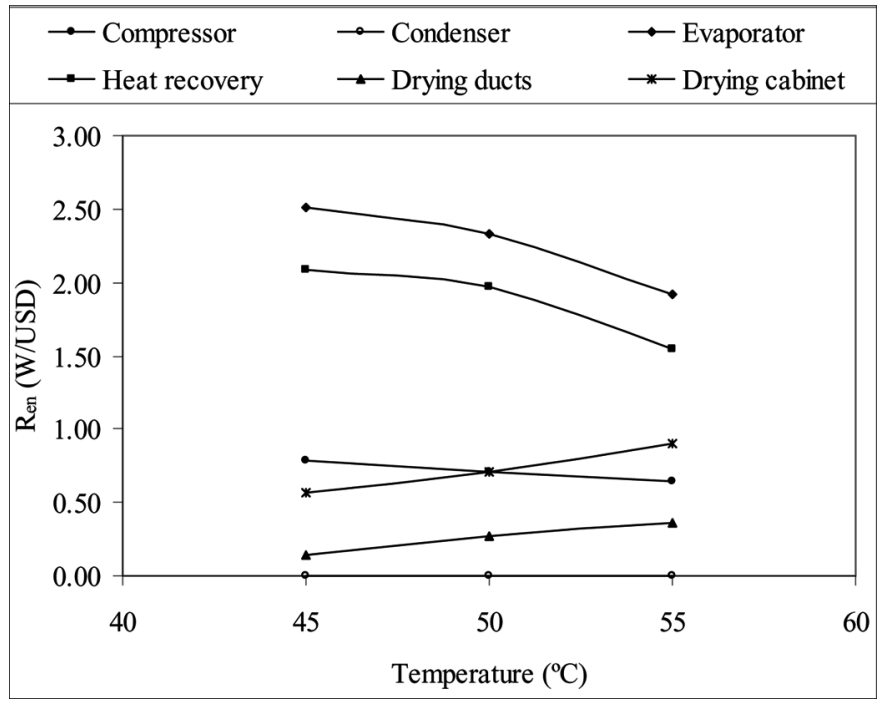

FIG. 4. Variation of $\dot{R}_{e n}$ for each component of the system with the different drying air temperatures.

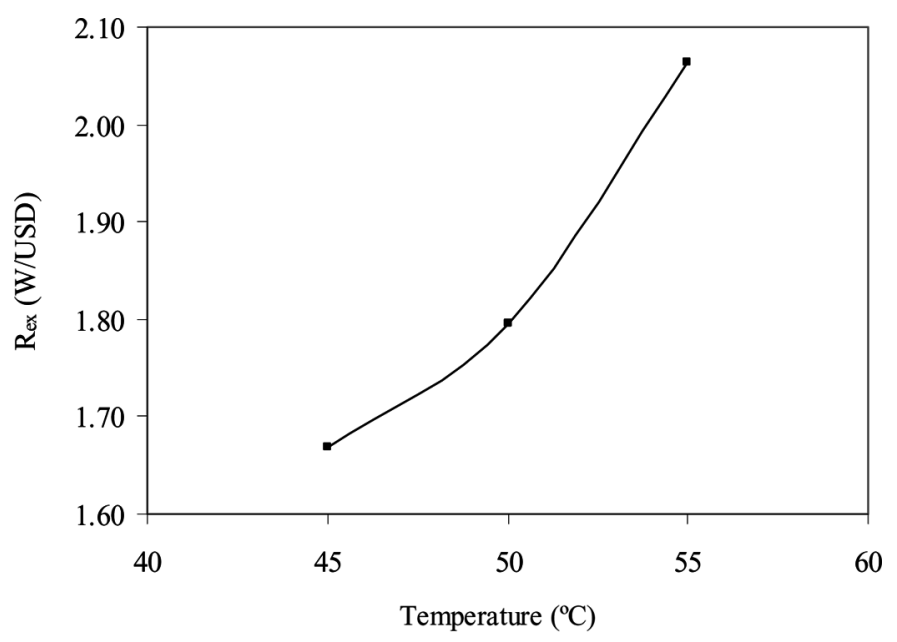

FIG. 5. Variation of $\dot{R}_{e x}$ with different drying air temperatures.

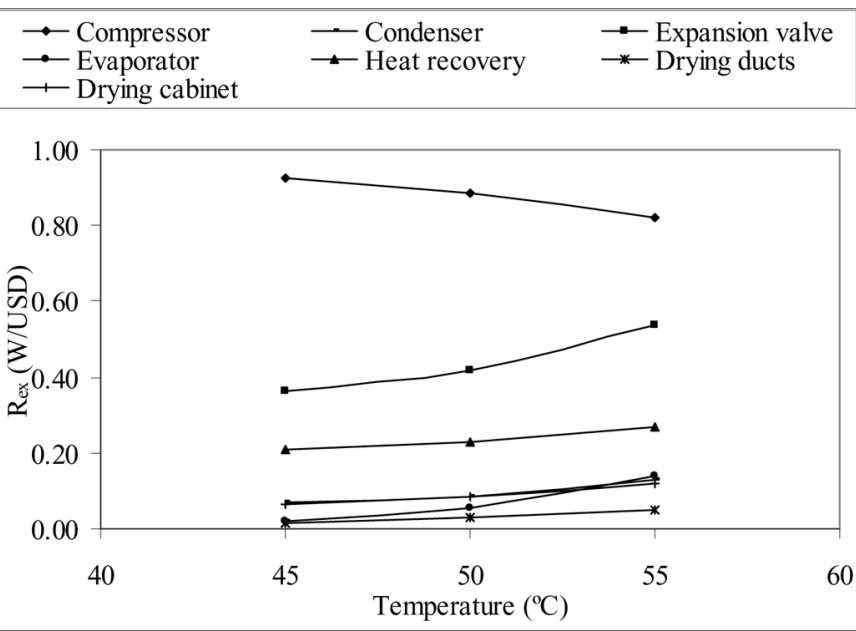

FIG. 6. Variation of $\dot{R}_{e x}$ for each component of the system with different drying air temperatures.

the relations between capital cost and total and internal exergy loss suggest that the collective characteristics of the system match and benefit the overall system. ${ }^{[17]}$

The value of $\dot{R}_{e x}$ may vary for different situations (e.g., technology, time, location, resource costs, knowledge, air temperature due to exergy loss). For example, the values of $R_{e x}$ may be different for different technologies. Also, during periods when energy-resource costs increase (as was the case in many locations in the 1970s), the value of $\dot{R}_{e x}$ likely decreases (i.e., greater capital is invested to reduce losses). ${ }^{[17]}$

\section{CONCLUSIONS}

In this study, an exergoeconomic analysis of a heat pump dryer was made using experimental values and the 
EXCEM method. The following main conclusions may be drawn from the main results of the present study:

1. The most important system component of the HP dryer was the motor-compressor assembly because of the highest improvement potential rate and exergetic factor values.

2. The HP dryer had the highest exergetic efficiency values in the range of $72.72-75.66 \%$.

3. The $C O P_{H P \text {,theoretical }}$ values were found to be in the range of 3.92-4.35 and the $C O P_{H P, \text { actual }}$ values were obtained to vary from 2.56 to 2.81 for the HP unit.

4. $\dot{R}_{e x}$ values were found to range from 1.668 to $2.063 \mathrm{~W} /$ USD.

5. $\dot{R}_{e n}$ values were observed to be between 6.258 and $5.749 \mathrm{~W} /$ USD for the whole system with drying air temperatures of 45,50 , and $55^{\circ} \mathrm{C}$.

6. The exergoeconomic analysis used here to search for the optimal design of the HP drying systems should be extended to other related systems to achieve greater increases in energy savings. This conclusion is important, given the increasing influence of heat pumps (with higher energy utilization efficiencies compared to conventional systems) and drying (an energy-intensive process) in global energy consumption.

\section{NOMENCLATURE}

$\begin{array}{ll}C & \text { Specific heat }\left(\mathrm{kJ} \mathrm{kg}^{-1} \mathrm{~K}^{-1}\right) \\ \dot{E} & \text { Energy rate }\left(\mathrm{kJ} \mathrm{s}^{-1} \text { or kW) }\right. \\ \dot{E} x=3.353 & \text { Exergy rate }(\mathrm{kW}) \\ e x & \text { Specific exergy }\left(\mathrm{kJ} \mathrm{kg}^{-1}\right) \\ F & \text { Function of the independent variables } \\ \dot{F} & \text { Exergy rate of the fuel (or exergetic fuel rate) } \\ & (\mathrm{kW}) \\ h & \text { Specific enthalpy }\left(\mathrm{kJ} \mathrm{kg}^{-1}\right) \\ I & \text { Current }(\text { A) } \\ I \dot{P} & \text { Improvement potential rate }(\mathrm{kW}) \\ K & \text { Capital cost }(\mathrm{USD}) \\ \dot{L} & \text { Thermodynamic loss rate }(\mathrm{kW}) \\ m & \text { Mass }(\mathrm{kg}) \\ \dot{m} & \text { Mass flow rate }\left(\mathrm{kgs}^{-1}\right) \\ P & \text { Pressure }(\mathrm{kPa}) \\ \dot{Q} & \text { Heat transfer rate }\left(\mathrm{kW}^{-1}\right) \\ \mathrm{R} & \text { Gas law constant }\left(\mathrm{kJ} \mathrm{kg}^{-1} \mathrm{~K}^{-1}\right) ; \text { ratio of } \\ & \text { thermodynamic loss rate to capital cost }(\mathrm{kW} \\ & \text { USD } \\ S & \text { Specific entropy }\left(\mathrm{kJ} \mathrm{kg}^{-1} \mathrm{~K}^{-1}\right) \\ T & \text { Temperature }\left({ }^{\circ} \mathrm{C} \text { or K) }\right. \\ V & \text { Voltage }(\mathrm{V}) \\ \dot{W} & \text { Work rate or power }\left(\mathrm{kW}^{-1}\right)\end{array}$

\section{Greek Symbols}

$\begin{array}{ll}\eta & \text { Exergetic efficiency (\%) } \\ \varnothing & \text { Relative humidity of air (\%) }\end{array}$

$\omega$

\section{Subscripts}

a

act

$b$

comp

cond

$d$

$d c a b$

dduct

elec

en

ex

$\exp$

evap

$H P$

in

mech

out

$r$

recovery

$s$

$v$

$w$

0

Overdot
Absolute humidity of air [ $\mathrm{kg}$ water $(\text { kg dry air })^{-1}$ ]

Air

Actual

Boundary or surface location

Compressor

Condenser

Destruction or destroyed

Drying cabinet

Drying ducts

Electrical

Energy

Exergy

Expansion valve

Evaporator

Heat pump

Inflow

Mechanical

Outflow

Refrigerant

Heat recovery unit

Isentropic

Vapor

Water

Dead (reference) state

Quantity per unit time

\section{ACKNOWLEDGMENTS}

The authors are grateful for the financial support provided for the project "Design, Test and Performance Evaluation of a Gas Engine-Driven Solar Assisted Band Conveyor Heat Pump Drying System" under project no. 106 M482 by the Scientific and Technological Research Council of Turkey (TUBITAK). They are also grateful to the reviewers for the valuable comments, which have been utilized to improve the quality of the article, as well as to Associate Editor Dr. Sakamon Devahastin for his constructive comments and prompt review process.

\section{REFERENCES}

1. Mujumdar, A.S. Drying fundamentals. In Industrial Drying of Foods; Baker, C.G.J., Ed.; Chapman \& Hall: London, 1997; 7-30.

2. Erbay, Z.; Icier, F. A review of thin layer drying of foods: Theory, modeling and experimental results. Critical Reviews in Food Science and Nutrition 2010, 50, 441-464.

3. Keey, R.B. Introduction. In Drying Principles and Practice; Keey, R.B., Ed.; Pergamon Press: Oxford, 1972; 1-18.

4. Dincer, I.; Sahin, A.Z. A new model for thermodynamic analysis of a drying process. International Journal of Heat and Mass Transfer 2004, 47, 645-652.

5. Kuzgunkaya, E.H.; Hepbasli, A. Exergetic performance assessment of a ground-source heat pump drying system. International Journal of Energy Research 2007, 31, 760-777. 
6. Radivoje, T. Mathematical model for exergy analysis for drying plants. Drying Technology 1995, 13 (1), 437-445.

7. Bruttini, R.; Crosser, O.K.; Liapis, A.I. Exergy analysis for the freezing stage of the freeze drying process. Drying Technology 2001, 19 (9), 2303-2313.

8. Syahrul, S.; Dincer, I.; Hamdullahpur, F. Thermodynamic modeling of fluidized bed drying of moist particles. International Journal of Thermal Sciences 2003, 42, 691-701.

9. Ozgener, L.; Ozgener, O.; Exergy analysis of drying process: An experimental study in solar greenhouse. Drying Technology 2009, 27 (4), 580-586.

10. Kuzgunkaya, E.H.; Hepbasli, A. Exergetic evaluation of drying of laurel leaves in a vertical ground-source heat pump drying cabinet. International Journal of Energy Research 2007, 31, 248-258.

11. Colak, N.; Hepbasli, A. Performance analysis of drying of green olive in a tray dryer. Journal of Food Engineering 2007, 20, 1188-1193.

12. Colak, N.; Kuzgunkaya, E.; Hepbasli, A. Exergetic assessment of drying of mint leaves in a heat pump dryer. Journal of Food Process Engineering 2008, 31, 281-298.

13. Aghbashlo, M.; Kianmehr, M.H.; Arabhosseini, A. Energy and exergy analyses of thin-layer drying of potato slices in a semi-industrial continuous band dryer. Drying Technology 2008, 26, 1501-1508.

14. Erbay, Z.; Icier, F. Optimization of hot air drying of olive leaves using response surface methodology. Journal of Food Engineering 2009, 91 (4), 533-541.

15. Erbay, Z.; Icier, F. Optimization of drying of olive leaves in a pilot scale heat pump dryer. Drying Technology 2009, 27 (3), 416-427.

16. Sahoo, P.K. Exergoeconomic analysis and optimization of a cogeneration system using evolutionary programming. Applied Thermal Engineering 2008, 28, 1580-1588.

17. Rosen, M.A.; Dincer, I. Exergoeconomic analysis of power plants operating on various fuels. Applied Thermal Engineering 2003, 23, 643-58.

18. Tsatsaronis, G.; Winhold, M. Exergoeconomic analysis and evaluation of energy conversion plants. Parts $1 \& 2$. Energy-The International Journal 1985, 10, 69-80.

19. Rosen, M.A. The relation between thermodynamic losses and capital costs for a modern coal-red electrical generation station. In Computer-Aided Energy Systems Analysis, Vol. 21; Tsatsaronis, G., Bajura, R.A., Kenney, W.F., Reistad, G.M., Eds.; American Society of Mechanical Engineers: New York, 1990; 69-78.

20. Tsatsaronis, G. A review of exergoeconomic methodologies. In Second Law Analysis of Thermal Systems; Moran, M.J.; Sciubba, E., Eds.; American Society of Mechanical Engineers: New York, 1987; 81-87.

21. Utlu, Z.; Hepbasli, A. Thermoeconomic analysis of energy utilization in the residential-commercial sector: An application. Building and Environment 2008, 43, 896-904.

22. Tsatsaronis, G.; Park, M. On avoidable and unavoidable exergy destructions and investment costs in thermal systems. Energy Conversion and Management 2002, 43, 1259-1270.

23. Colpan, C.O.; Yesin, T. Energetic, exergetic and thermoeconomic analysis of Bilkent combined cycle cogeneration plant. International Journal of Energy Research 2006, 30, 875-894.

24. Abusoglu, A.; Kanoglu, M. Exergetic and thermoeconomic analyses of diesel engine powered cogeneration: Part 1-Formulations. Applied Thermal Engineering 2009, 29, 234-241.

25. Menges, H.O.; Ertekin, C. Thin layer drying model for treated and untreated Stanley plums. Energy Conversion and Management 2006, 47, 2337-2348.

26. Tarhan, S. Selection of chemical and thermal pretreatment combination for plum drying at low and moderate drying air temperatures. Journal of Food Engineering 2007, 79, 255-260.

27. Anonymous. Dry matter content. In Official Methods of Analysis of the Association of Official Analytical Chemists; Helrich, K., Ed.; AOAC Inc.: Arlington, VA, 1990; 1298.
28. Erbay, Z.; Icier, F.; Hepbasli, A. Exergetic performance assessment of a pilot scale heat pump belt conveyor drier. International Journal of Energy Research 2010, 34, 249-264.

29. Çengel, Y.A.; Boles, M.A. Thermodynamics: An Engineering Approach, 5th ed.; McGraw-Hill: New York, NY, 2006.

30. F-Chart Software. Engineering Equation Solver Ver. 8.156D; F-Chart Software; Madison, WI, 2008.

31. Hepbasli, A.; Balta, M.T. A study on modeling and performance assessment of a heat pump system utilizing low temperature geothermal resources in buildings. Building and Environment 2007, 42, 3747-3756.

32. Van Gool, W. Energy policy: Fairly tales and factualities. In Innovation and Technology-Strategies and Policies; Soares, O.D.D.; Martins da Cruz, A.; Costa Pereira, G.; Soares, I.M.R.T.; Reis, A.J.P.S., Eds.; Kluwer Academic Publishers: Dordrecht, The Netherlands, 1997; 93-105.

33. Hammond, G.P.; Stapleton, A.J. Exergy analysis of the United Kingdom energy system. Proceedings of the Institution of Mechanical Engineer 2001, 215 (2), 141-162.

34. Hepbasli, A.; Erbay, Z.; Icier, F.; Colak, N.; Hancioglu, E. A review of gas engine driven heat pumps (GEHPs) for residential and industrial applications. Renewable and Sustainable Energy Reviews 2009, 13 (1), 85-99.

35. Lian, Z.; Park, S.; Huang, W.; Baik, Y.; Yao, Y. Conception of combination of gas-engine-driven heat pump and water-loop heat pump system. International Journal of Refrigeration 2005, 28, 810-819.

36. Zhang, R.R.; Lu, X.S.; Li, S.Z.; Lin, W.S.; Gu, A.Z. Analysis on the heating performance of a gas engine driven air to water heat pump based on a steady-state model. Energy Conversion and Management 2005, 46, 1714-1730.

37. Chua, K.J.; Chou, S.K.; Ho, J.C.; Hawlader, M.N.A. Heat pump drying: Recent developments and future trends. Drying Technology 2002, 20 (8), 1579-1610.

38. Kudra, T.; Mujumdar, A.S. Advanced Drying Technologies; Marce Dekker: New York, NY, 2002.

39. Alves-Filho, O. Combined innovative heat pump drying technologies and new cold extrusion techniques for production of instant foods. Drying Technology 2002, 20 (8), 1541-1557.

40. Pal, U.S.; Khan, M.K.; Mohanty, S.N. Heat pump drying of green sweet pepper. Drying Technology 2008, 26 (12), 1584-1590.

41. Mohanraj, M.; Chandrasekar, P.; Sreenarayanan, V.V. Performance of a heat pump drier for copra drying. Proceedings of the Institution of Mechanical Engineers, Part A: Journal of Power and Energy 2008, 222 (3), 283-287.

42. Lee, K.H.; Kim, O.J. Investigation on drying performance and energy savings of the batch-type heat pump dryer. Drying Technology 2009, 27 (4), 565-573.

\section{APPENDIX}

Mass and energy balances as well as exergy destructions and exergetic efficiencies obtained from exergy balances for each of the drying system components illustrated in Fig. 1 were derived as follows:

Drying cabinet (I):

$$
\eta_{d c a b}=\frac{\dot{E} x_{6, a}}{\dot{E} x_{5, a}}
$$


Compressor (II):

$$
\begin{gathered}
\dot{W}_{\text {comp }, \text { elec }}=\frac{V_{\text {comp }} \cdot I_{\text {comp }} \cdot \sqrt{3}}{1000} \cdot \operatorname{Cos} \varphi \\
\dot{W}_{\text {comp }}=\dot{W}_{\text {comp }, \text { elec }} \eta_{\text {comp }, \text { elec }} \eta_{\text {comp }, \text { mech }} \\
\eta_{\text {comp }}=\frac{\dot{E} x_{2, r, a c t}-\dot{E} x_{1, r}}{\dot{W}_{\text {comp }}}
\end{gathered}
$$

Condenser (III):

$$
\eta_{c o n d}=\frac{\dot{E} x_{1, a}-\dot{E} x_{7, a}}{\dot{E} x_{2, r, a c t}-\dot{E} x_{3, r}}
$$

Expansion valve (IV):

$$
\eta_{\exp }=\frac{\dot{E} x_{4, r}}{\dot{E} x_{3, r}}
$$

\section{Evaporator (V):}

$$
\eta_{\text {evap }}=\frac{\dot{E} x_{5, a}-\dot{E} x_{6, a}}{\dot{E} x_{1, r}-\dot{E} x_{4, r}}
$$

Heat recovery unit (VI):

$$
\eta_{\text {recovery }}=\frac{\dot{E} x_{7, a}+\dot{E} x_{6, a}}{\dot{E} x_{4, a}+\dot{E} x_{5, a}}
$$

Drying ducts (VII):

$$
\begin{gathered}
\eta_{d d u c t, 1}=\frac{\dot{E} x_{2, a}}{\dot{E} x_{1, a}} \\
\eta_{d d u c t, 2}=\frac{\dot{E} x_{4, a}}{\dot{E} x_{3, a}} \\
\eta_{d d u c t, t o t a l}=\frac{\dot{E} x_{2, a}+\dot{E} x_{4, a}}{\dot{E} x_{1, a}+\dot{E} x_{3, a}}
\end{gathered}
$$

